\title{
HEAVY METAL COMPOSITION OF COMMERCIAL FERTILIZERS FROM ZARIA, NORTHERN NIGERIA
}

\author{
E. E. OGABIELA, E. D. PAUL, O. B. ADESINA, E. M. OKONKWO, J. O. OGBONNA AND S. M. AMANA
}

(Received 15, June 2007; Revision Accepted 10, September 2008)

\begin{abstract}
The heavy metal composition of some commercial fertilizers and soil supplements used in Zaria were analysed. The fertilizers analysed include Liquid Organic fertilizer, Palette Organic fertilizer, Urea, Super phosphate, NPK, some of the soil supplements analysed are cow dung and chicken droppings. Using Atomic Absorption Spectrophotometer (AAS) the following range of heavy metal concentrations were obtained: $\mathrm{Cu} 3.92-38.14 \mathrm{mg} / \mathrm{l}, \mathrm{Mn} 0.057-199.17 \mathrm{mg} / \mathrm{l}, \mathrm{Cr}$ 0.19-2.207mg/l, Zn 1.35-83.12mg/l, Fe 5.00-514.18mg/l, Ni 0.063-149mg/l, Pb 9.86-15.52mg/l, Co 0.26-2.87mg/l.. Super phosphate had the highest abundance of Iron $(514.18 \mathrm{mg} / \mathrm{l})$. These values were compared to standards for heavy metals in fertilizers and supplements for other countries and were found to be below the limits. Like other countries, it will be important for Nigeria to have set standards for heavy metals levels for fertilizers used in the country.
\end{abstract}

KEYWORDS: fertilizer, Heavy metal, supplements, composition, AAS

\section{INTRODUCTION}

For many years commercial fertilizers have been regulated to ensure that label provides accurate information on essential plant nutrient content. In recent years, however, concerns about quality in some fertilizer and liming products have extended beyond nutrient content to the potential presence of non nutrient toxic substances, such as heavy metals (Cooke, 1982). Plants in contrast to animals have the ability to convert carbon dioxide from the atmosphere and inorganic components of the earth directly into high-energy carbohydrates, fat, and protein. These plant materials are absolutely essential to human nutrition as well as to the nutrition of other animal species (Kirk-Othmer, 1993).

There is increasing interest in recycling of by-products and waste materials for land application as fertilizers and supplements. The obvious benefits from this practice include the return of a number of nutrients to soil and improvement of soil physical conditions (KirkOthmer, 1993).

The benefits associated with the use of fertilizers must be balanced against the potential hazards, which the materials may present. They may contain significant levels of metals which can at high exposure levels adversely affect plants, animals or humans (Underwood, 1977; Nicholas and Egan, 1975; Goyer and Clarkson, 2001). In response to this concern, numerous regulatory agencies have enacted policies for by-product utilization. In 1979, under the authority of the fertilizer Act and Regulations, Agriculture and Agri-Food Canada (AAFC) introduce a series of standard for metals in fertilizer and supplements, which were re-evaluated in 1993 and 1995 in response to the standards developed elsewhere e.g United State Environmental Protection Agency (Canadian Food Inspection Agency, 1997).

In Nigeria, there are no such standards for metals concentrations in fertilizers and supplements. In Kano, Nigeria, it was reported by Ogbonna et al (1998) that sludge and effluent from tanneries are used as soil conditioners despite the high chromium content of the effluent as reported by Agunwa et al (2006) because of the in ability of most of the tanneries to treat their waste before discharge.

The worldwide use of fertilizers has an important, positive effect on the environment. Conservative estimate indicates that $30 \%$ of the world food production is directly attributable to fertilizer use (Kirk-Othmer, 1993). Possible negative effects of fertilizer use include; deterioration of food quality, destruction of natural soil fertility, and pollution of ground and surface water.

Prudent use of fertilizer does not contribute to this problem (Kirk-Othmer, 1993). The aim of this work is to determine the levels of heavy metals in commercial fertilizers and supplements and compare them with values from other countries.

\section{MATERIALS AND METHODS}

Five brand of commercial fertilizers where obtained from Sabon Gari Market in Zaria and a sample of chicken droppings and cow dung were collected from two farms in Zaria. These samples were collected in plastic bags and plastic bottles for the liquid samples.

The samples were grounded sufficiently to pass a sieve having mesh size about $1 \mathrm{~mm}$ square. About $5 \mathrm{~g}$ of each

E. E. Ogabiela, National Research Institute for Chemical Technology, P.M.B 1052, Zaria, Nigeria.

E. D. Paul, National Research Institute for Chemical Technology, P.M.B 1052, Zaria, Nigeria.

O. B. Adesina, National Research Institute for Chemical Technology, P.M.B 1052, Zaria, Nigeria.

E. M. Okonkwo, National Research Institute for Chemical Technology, P.M.B 1052, Zaria, Nigeria

J. O. Ogbonna, National Research Institute for Chemical Technology, P.M.B 1052, Zaria, Nigeria.

S. M. Amana, Department of Soil Science, University of Nigeria, Nnsuka, Nigeria. 
Table I: Standards for Mineral element levels for some other Countries

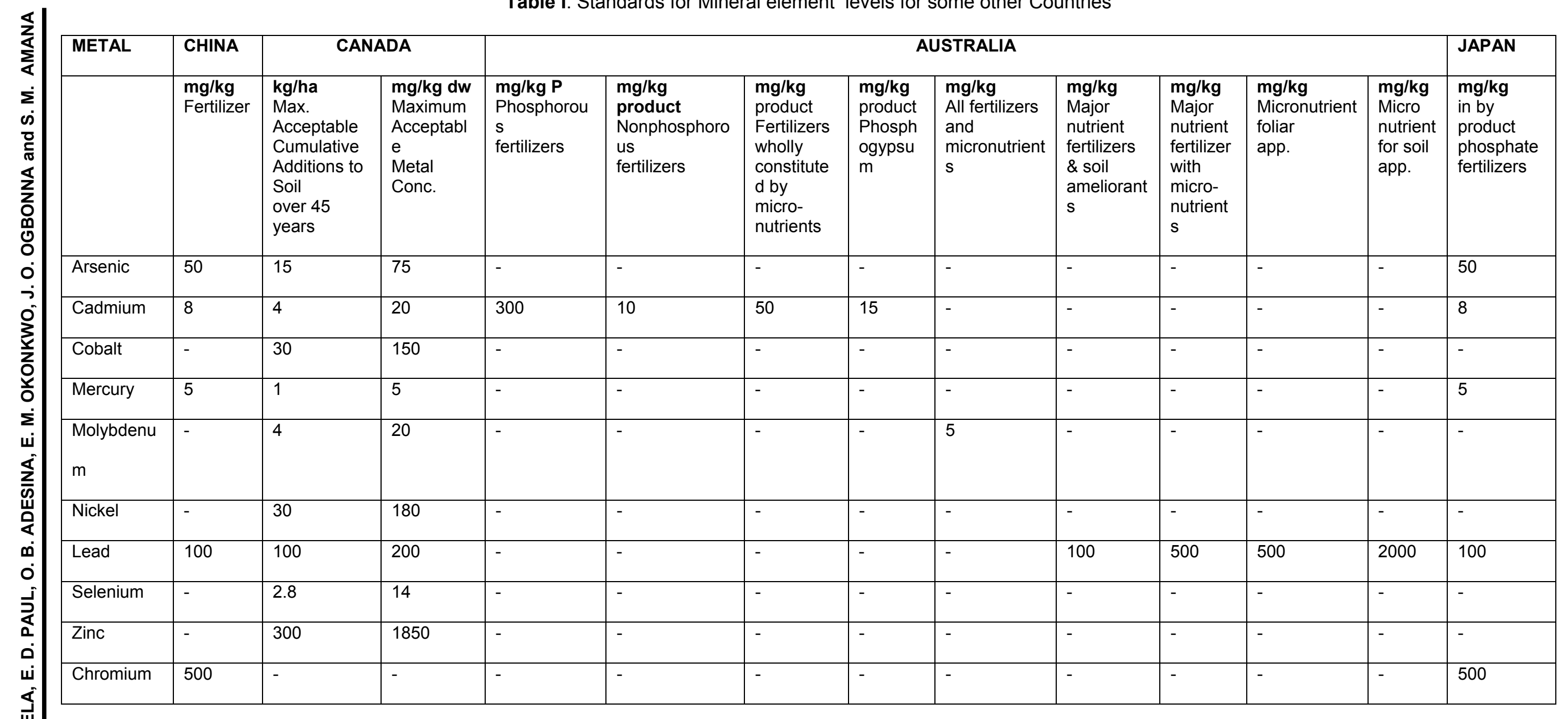


of the dried samples was placed into silica basin, covered with a silica clock glass, and placed in a muffle furnace, with the temperature raised to $450^{\circ} \mathrm{C}$ for $6 \mathrm{hrs}$. The samples were cooled, $10 \mathrm{ml}$ of $\mathrm{HCl}$ approx $6 \mathrm{~N}$ was added and evaporated to dryness on a water bath. The soluble salts were extracted from the residue with two successive $10 \mathrm{ml}$ portion of boiling diluted $\mathrm{HCl}$, approx $2 \mathrm{~N}$, decanting the solution each time through the same filter paper into a $50 \mathrm{ml}$ volumetric flask. $5 \mathrm{ml}$ of $\mathrm{HCl}$ and about $5 \mathrm{ml}$ of $\mathrm{HNO}_{3}(6 \mathrm{~N})$ was added to the residue in the basin and the solution was filtered through the same filter paper into the flask. The extracts were made to the mark with distilled water, washing the filter paper in the process (Hanson, 1973). The heavy metals were determined by Atomic Absorption Spectrophotometer (Unicam 969) using hollow cathode lamps in default condition and flame absorption mode. For reproducibility this analysis was carried out tries.

\section{RESULTS AND DISCUSSION}

\section{COPPER}

From fig. I, super phosphate fertilizer had the highest copper value of $83.67 \mathrm{mg} / \mathrm{kg}$ with NPK and chicken dung having values at $38.14 \mathrm{mg} / \mathrm{kg}$ and $34.30 \mathrm{mg} / \mathrm{kg}$ respectively. This high values in super phosphate could be due to the rock phosphate used, or from the sulphuric acid used to make the super, which might be a byproduct of processing ore (Cooke, 1982). Limits for copper level in soil being $50-140 \mathrm{mg} / \mathrm{kg}$ (see table II). Copper is important for photosynthesis. Symptoms for copper deficiency include chlorosis (Barber 1984).

Table II: Sewage Sludge Metal Level Standards

\begin{tabular}{|l|l|l|l|}
\hline METAL & $\begin{array}{l}\text { Limit Values for } \\
\text { Concentrations of } \\
\text { Heavy Metals in Soil } \\
\text { (Soil with } \mathbf{p H} \text { of } \mathbf{6}-\mathbf{7}) \\
\mathbf{m g} / \mathbf{k g}\end{array}$ & $\begin{array}{l}\text { Limit Values for Heavy-Metal } \\
\text { Concentrations in Sludge for } \\
\text { Use in Agriculture } \mathbf{m g} / \mathbf{k g}\end{array}$ & $\begin{array}{l}\text { Limit Values for Amounts of Heavy } \\
\text { Metals which may be Added Annually to } \\
\text { Agricultural Land (Based on 10-Year } \\
\text { Avg.) } \\
\mathbf{k g} / \mathbf{h a} / \mathbf{y r}\end{array}$ \\
\hline Cadmium & 1 to 3 & 20 to 40 & 0.15 \\
\hline Copper & 50 to 140 & 1000 to 1750 & 12 \\
\hline Nickel & 30 to75 & 300 to 400 & 3 \\
\hline Lead & 50 to 300 & 750 to 1200 & 15 \\
\hline Zinc & 150 to 300 & 2500 to 4000 & 0.1 \\
\hline Mercury & 1 to 1.5 & 16 to 25 & 4 \\
\hline Chromium & 100 to 150 & 1000 to 1500 & 30 \\
\hline
\end{tabular}

Source: World Fertilizer Metal Standard (2004). www.afpc.net

\section{MANGANESE}

From fig.1, Chicken dung has the highest value of $199.17 \mathrm{mg} / \mathrm{kg}$. Manganese is necessary for building the chloroplasts. Manganese deficiency may result in coloration abnormalities, such as discolored spots on the foliage (Simpson 1986).

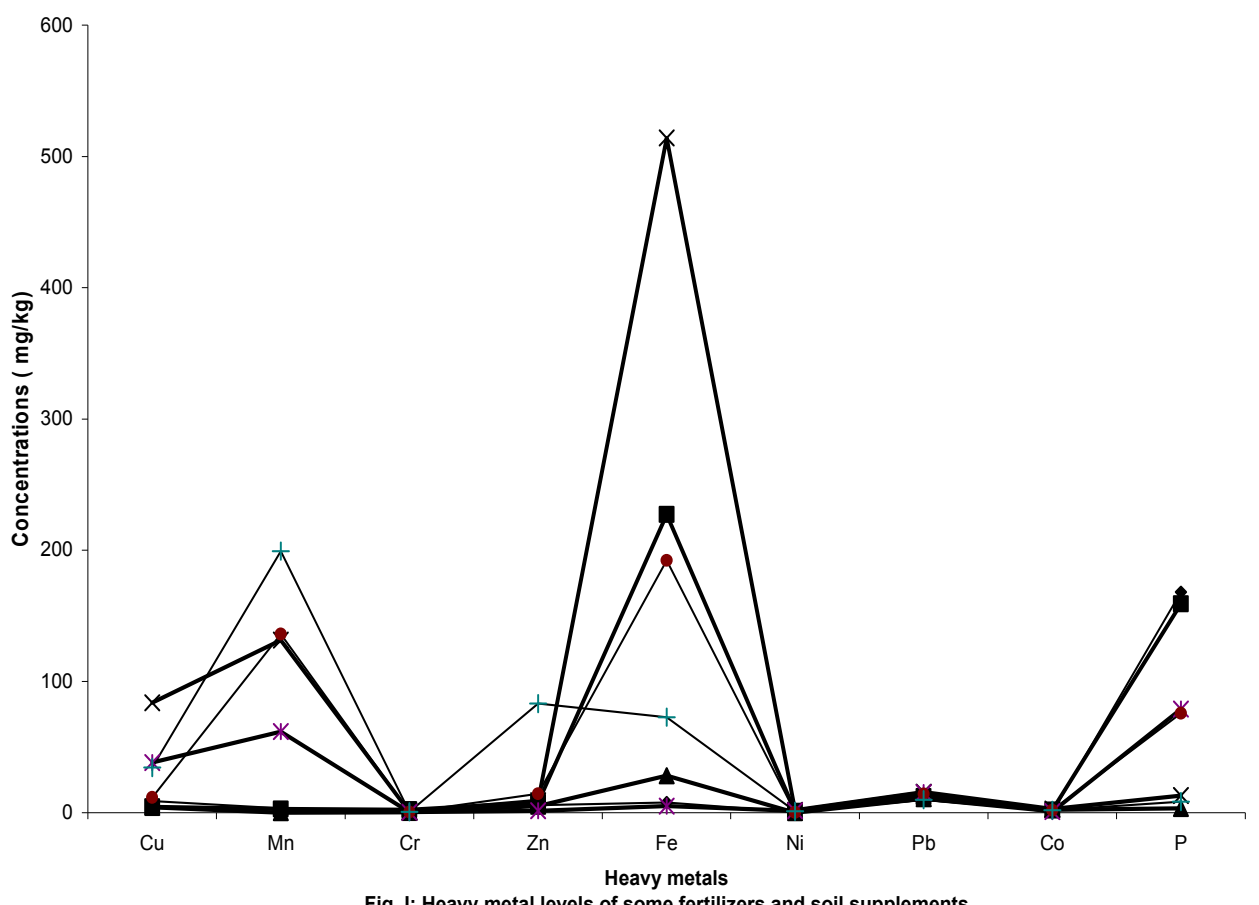

Fig. I: Heavy metal levels of some fertilizers and soil supplements

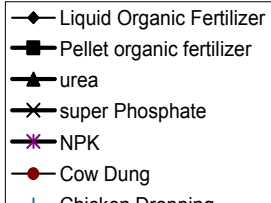

- - Chicken Dropping 


\section{IRON}

From fig.1, iron has the highest value of $514.18 \mathrm{mg} / \mathrm{kg}$ in super phosphate Iron is necessary for photosynthesis and is present as an enzyme cofactor in plants. Iron deficiency can result in interveinal chlorosis and necrosis (Barber 1984).

\section{ZINC}

From fig.1, chicken dung had the highest value of $83.12 \mathrm{mg} / \mathrm{kg}$, with Canadian standards for Zinc being $1850 \mathrm{mg} / \mathrm{kg}$ (see table I). Zinc is required in a large number of enzymes and play an essential role in DNA transcription. A typical symptom of zinc deficiency is the stunted growth of leaves, commonly known as "little leaf" and is caused by the oxidative degradation of the growth hormone auxin (Cooke 1982).

\section{PHOSPHORUS}

From fig.1, liquid fertilizer has the highest value of $168 \mathrm{mg} / \mathrm{kg}$. Phosphorus is important in plant bioenergetics. As a component of ATP, phosphorus is needed for the conversion of light energy to chemical energy (ATP) during photosynthesis. Phosphorus can also be used to modify the activity of various enzymes by phosphorylation, and can be used for cell signaling. Since ATP can be used for the biosynthesis of many plants bio-molecules, phosphorus is important for plant growth and flower/seed formation (Simpson 1986).

\section{LEAD, NICKEL, COBALT, AND CHROMIUM}

Some of the non-essential nutrient that were analysed include $\mathrm{Pb}, \mathrm{Ni}, \mathrm{Co}$, and $\mathrm{Cr}$. From fig. I, $\mathrm{Pb}$ has the highest value of $15.52 \mathrm{mg} / \mathrm{kg}$ in super phosphate fertilizer; standard for lead in fertilizer are $100 \mathrm{mg} / \mathrm{kg}$ for China and $500 \mathrm{mg} / \mathrm{kg}$ for Canada (see table I). Lead is especially prone to accumulation in surface horizons of soil because its low water solubility within an environmentally relevant $\mathrm{pH}$ range results in very low mobility (Davies, 1995). Neurological problems, especially in children, are the principal concern for chronic lead exposure (Goyer and Clarkson, 2001). Past use of lead solder in food and beverage can lead to significant human exposures. Dietary intakes of 400 to $500 \mu \mathrm{g} /$ day for Canada dropped to $20 \mu \mathrm{g} /$ day with the elimination of this practice. Consumption of lead contaminated soil itself, rather than crop contamination , is a more likely exposure hazard.

Super phosphate fertilizer still has the highest Nickel value of $1.89 \mathrm{mg} / \mathrm{kg}$, limits been $180 \mathrm{mg} / \mathrm{kg}$ for Canada. Super phosphate fertilizer still had the highest Cobalt value being $2.87 \mathrm{mg} / \mathrm{kg}$, limits for Canada is $150 \mathrm{mg} / \mathrm{kg}$ (see table I). Nickel is moderately soluble in soil water and is typically true for metals, increases at low $\mathrm{pH}$ (McGrath, 1995). The predominant soluble species in most agricultural soil is $\mathrm{Ni}^{2+}$. Nikel sulphides likely controls the $\mathrm{Ni}^{2+}$ concentrations in soil solution. The Nickel concentration in plant generally reflects that of their soils and plant transfer coefficients range from 0.11.0. Inhalation of nickel during refining of ore produces respiratory tract cancer, and allergic contact dermatitis to nickel alloy is common (Goyer and Clarkson, 2001). Aside from this problem Nickel toxicity appears quite low. It is a naturally essential metal for some plants, microbes, and invertebrates. There is no known biochemical function for Nickel in humans. Crop contamination with Nickel in fertilizers and related products seems an unlikely human health problem.

Organic fertilizer had the highest Chromium value of $2.21 \mathrm{mg} / \mathrm{kg}$, while the standard for chromium in fertilizer for China is $500 \mathrm{mg} / \mathrm{kg}$. Cr (IV) is a well epithelial irritant and human carcinogen (IARC, 1990). It is also toxic to many plants, aquatic animals and bacteria (USEPA, 1985). From the results in Table I, compared to standards from other parts of the world, the mineral elements present in these fertilizers are within the safe limits for addition to the soil.

\section{CONCLUSION}

Fertilizers made from naturally occurring raw material may contain appreciable quantities of micronutrients. Farm yard waste, like the cow dung and chicken dropping may contain varying amount of micronutrients based on their feed and the housing system used (Cooke 1982). Comparing the concentrations of heavy metals present in these fertilizers to set standards from other parts of the world, the levels are within safe limits for addition to soil. It will be important for the Nigerian Government to have her own standards for heavy metals in fertilizer; this will help in checking both essential and non-essential heavy metals that are added to the soil. Since use of fertilizers and related products is a repetitive practice, it is also necessary to consider cumulative changes in the soil over decades of applications.

\section{REFERENCES}

Agunwa, U.B., Ogabiela, E.E., Lawal, F.A and Owoeye, L. D., 2006.. Analysis of Effluent from Challawa Industrial Estate of Kano Nigeria. Global Journal of Pure and Applied Sciences. 12(1): 67-72.

Barber S. A., 1984. Soil nutrient bioavailability, a mechanistic approach. John Wiley and Sons Inc. New York. p 201-228.

Canadian Food Inspection Agency, 1997. Standards for Metals in Fertilizers and Supplements. p 1-4.

Cooke G. W., 1982. Fertilizing for maximum yield $\left(3^{\text {rd }}\right.$ ed.). Richard Clay Ltd, Bungay Sufflok. p 179 192.

Davies, B. E., 1995. Lead. In, Heavy metals in soils. $2^{\text {nd }}$ Ed (Alloway, B.J. ed). Blackie, New York. p 206223.

Goyer, R. A. and Clarkson, T. W., 2001. Toxic effects of Metals. In, Caserett and Doullis Toxicology, The basic Science of Poisons. $6^{\text {th }}$ Ed (Klaassen, C.D ed). Mc-Graw-Hill, New York. p 811-867.

Hanson, N. W., 1973. Official Standardized and Recommended methods for Analysis compiled and edited for The Analytical Method Committee of The Society for Analytical Chemistry. The Society for Analytical Chemistry, London, 9-10 Savile Row, London WIX 1AF. p 2260-2291. 
IARC 1990. Chromium, Nikel and Welding Mongr. On the Evaluation of Carcinogenic Risk to Humans. Lyon, France, International Agency for Research on Cancer, 49.

Kirk-Orthmer Encyclopedia of Chemical Technology Fourth Edition, 1993. John Willey and Sons. Inc. 605, Third Avenue, New York, p 433-510.

McGrath, S. P., 1995. Chromium and Nikel. In, Heavy Metals in Soils, $2^{\text {nd }}$ Edition (Alloway, B.J. ed). Blackie, New York. p 152-178.

Nicholas, D. J. and Egan, A. R., 1975. Trace elements in soil-plant-animal systems. New York: Academic press. p 20

Ogbonna, O. O., Lawal, F. A., Owoeye, L. D., and Udeh, M. U., 1998. Chemical Characteristics and fertilizing
Value of Sludge from Tannery Effluent Treatment Plant. Proceedings of the $16^{\text {th }}$ Annual Conference of the Nigerian Institute of Science and Technology. $24^{\text {th }}-27^{\text {th }}$ Nov, 1998, Ibadan.

Simpson, K., 1984. Fertilizer and Manures. Longman Inc. New York. Page 1-10.

Underwood, E. J., 1977. Trace Elements in Human and Animal Nutrition $\left(4^{\text {th }}\right.$ ed). New York: Academic press.

USEPA (1985). Ambient water Quality Criteria for Chromium. Washington, D.C., Office of Regulations and Standards and Criteria and standards Div., U.S. Envrionmental protection Agency.

World Fertilizer Metal Standard (2004). www.afpc.net. 